\title{
Fodbold mellem myter og kilder
}

\author{
af Jim Toft
}

Artiklen tager et meget personligt udgangspunkt for at vise, hvordan man (jeg) som person fortolker og forstår sig selv relativt med historiens skiftende vingesus. Dette kunne ligså godt være et billede af fodboldspillets historiografi med skiftende fortolkning af fodboldspillets psykologiske og kulturelle rolle. Efter indledningen forsøger artiklen at analysere og forholde sig kritisk til de mange myter omkring fodboldspillets historie. Historikeren er ofte den kedelige, der gemmer sig bag kilderne og frelst distancerer sig til et hvert teoritiltag. Artiklen gendriver (desværre) på mange måder myterne - mytologiens hverdagsbevidsthed er jo mere spændende fremfor kedelige sandheder. Artiklen er mere historisk end my tisk - men er samtidig udtryk for en kærlighed til emnet, som jeg håber skinner igennem $\mathrm{i}$ fremstillingen.

\section{Fra utopi til arbejdsfordobling til utopi}

Gladsaxe engang i slutningen af 1960'erne og begyndelsen af 1970'erne:

Gladsaxe en ubetydelig og for de fleste en uvedkommende flække et eller andet sted indeomkring magtens centrum i Kongeriget Danmark - men vel alligevel kendt af defleste som ,Borgmester Erhard Jacobsens Paradis", og hele Danmarks elektoniske medium DR's TV-byen er beliggende her i Gladsaxe midt i Gyngemosen. TV-byen var ikke eneste by der i velfærdsstatens begyndende dage blev opført i og omkring Gyngemosen. Mastodont-byggeriet „Høje Gladsaxe“ med sine ca. 2000 (totusinde) lejligheder blev smækket op i løbet af et par år - hvilket absolut kun kunne lade sig gøre ved at bygge med højmoderne præfabrikerede betonplader. Arbejdere, funktionærer og andre helt almindelige lønmodtagere var glade
- her fik man mulighed for at flytte fra Københavns brolejligheder uden bad og med fællestoilet på køkkentrappen ud til hypermoderne lejligheder med rindende varmt vand og elkomfur. En by i byen - sammenbragt fra nær og fjern og samlet i et ,fællesskab", uden at en eneste kendte hinanden på forhånd. Såvel arbejderunger som funktionærunger blev stuvet sammen i lokalerne i den nyopførte skole med alle middelklassens mest moderne pædagogikker-ligefra Summerhill til ortodoks struktureret pædagogik. Et socialt og kulturelt eksperiment hvor klassens seje overlevede og de svage bukkede under, og en 4-5 stykker har i dag fast plads på en eller anden obskur samfundsinstitution.

Hele komplekset udgjorde en enklave, man egentlig ikke behøvede at forlade, hvis man da ikke var så uheldig at være voksen og have arbejde - skolen, indkøbscentret, daginstitutioner, idrætsanlæg, legepladser etc. lå indenfor rækkevidde og i selve enklaven. Rundt om bygningerne lå ca. $25 \mathrm{tdr}$. land til fri afbenyttelse for alle os unger: byggelegeplads, mose, sø, skov, mark, vold, græsplæner, parkeringsområder og vigtigst af alt 4 fodboldbaner tilgængelige og udenfor de voksne hegemonier - et sandt paradis for børn; og vi beton-unger betakkede os for de asfaltveje, ungerne i de fine villakvarterer var henvist til.

Godt nok var vi en skrup umulig klasse, som vores mange forskellige klasselærere sagde til os (de holdt kun ca 2 år ad gangen), men fodbold $\mathrm{ku}^{\prime}$ vi til gengæld spille. Vi var tilfældigvis samlet 3 knægte i samme klasse, der spillede på samme hold i samme klub på måske Danmarks bedste hold i de lige år 1968-1970-1972, sådan lød historien i hvert fald. Fodbold - herfra vores verden gik - alt blev tænkt i forlængelse af fodbold - hvert sekund blev udnyttet. Man løb til skole ved 
at sparke en fodbold foran sig, pakkede den omhyggeligt sammen ind til frikvarteret, udfordrede de andre større klasser - efterhånden aldrig vores parallelklasser de var barnemad - hjemturen fra skole gik også med at sparke fodbolden foran sig, hjem i gården, hvor man blot skulle stå i 5 minutter og sparke bolden op af betonvæggen, så var der efterhånden samlet nok til 2 hold, og kl. 5 stod vi mandag, onsdag og fredag til træning i klubben og kamp i week-enden, se' fø'li. Alt andet var ligegyldigt - og det værste var familieudflugter i weekenden - en uudholdelig tanke at være bænket fast $i$ et røvsygt sommerhus med voksensnak om penge og Kong Frederik med ølbøvseri og koneopvask, mens kammeraterne løb rundt derhjemme og spillede fodbold. Hele vores liv lå i forlængelse af fodbolden - hele vores stofskifte var indstillet til fodbold ... fodbold ... På en almindelig lørdag/søndag spillede vi ofte 7-8 timers fodbold, aldrig en hviledag - en ufattelig mængde selv for de skrappeste fuld tidsprofessionelle fodboldspillere. Fodbolden var en verden for sig - et realiseret utopia. Fodbolden blev et forsøg på at skabe en total ubekymrethed, som oven i købet gav prestige. Efter at vi havde banket Kenneth Brylle og kompagni fra Hvidovre i Pokalfinalen, stod der aldrig under 100 tilskuere til vores hjemmekampe-nogen gange 2-300 - et tal selv de fine ude fra $A B$ i den anden ende af kommunen vil være glade for i dag til deres 2. divisionskampe. Hele bestyrelsen for den gamle arbejderklub Hero stod dér og drømte sig op i 1. division.

Men alt blev sprængt i stumper og stykker da vi, eller rettere nogen af os fik en snigende fornemmelse af, at vores liv, fremtid, identitet, selvfølelse, uddannelse og øldrikkeri ikke var at finde indenfor fodboldklubbens rammer. Samtidig begyndte vi at hade klubbens og trænerens stigende krav til vores efterhånden udvoksede kroppe - ja ikke blot kroppen men også livsførelsen - en omklamring selv ikke kærligheden til fodbolden eller prestigen kunne holde ud.

Københavns Universitet - Historisk Institut 1977:

Fodboldens utopi blev skiftet ud med Marx' og Maos utopiske verdener. Nu lå livet ikke længere i forlængelse af fodbolden men Kapitalen og "Den lille røde“. Alt blev forstået, fortolket og „følt med røde øjne, røde sanser og den røde ånd“. Med Marx og Rigauer under armen forstod vi os selv og den øvrige menneskehed i den vestlige verden som ideologiskabte fremmedvæsener, hvor sportens habitus var ypperste-repræsentant for falsk bevidsthed. Sporten var skabt af kapitalens hegemoni -ikke nok med at arbejderens stofskifte blev brugt til udbytningi produktionens maksimeringslogik, men også sporten var opfundet til at reproducere arbejderens stofskifte i fritiden og ligeledes her var logikken en brug af kroppen til maksimering. Sportens stoftskifte var en arbejdsfordobling. Sporten blev lagt ovenpå en 8 timers arbejdsdag.

Især den akademiske verden smøgede ærmerne op-sanserne sku' renses for kapitalens ideologihegemoni. Kulturlivet og mennesket sku' omdefineres - et tungt arbejde lå forude. Basisgrupper opstod som paddehatte, hvor man hver især bekendte fortidens synder: ,Jeg har spillet fodbold siden jeg var knægt, men jeg er idag afvænnet og spiller ikkelængere fodbold ". Det nye kodeord ud af moradset blev "rød sanselighed", som langsomt „udvikledes" i basisgrupperne. Møderne i basisgruppen blev en utrolig lettelse - en slags hjælpende hånd til for endeligt at komme over de ar, bruddet med fodboldens utopia havde givet. Afsavnet af klublivet, kammeratskabet, legen med klatten, den intense stemning omkring de vigtige fodboldkampe blev lettere at holde ud og sige definitivt farvel til. Nu om dage vil det nok hedde "et slags sorgarbejde".

\section{Tiderne skifter}

Arrene sad dybere end som så - fodbolden lå stadig og flød rundt i årerne på os tossede fodboldidioter. Da fag-og ideologikritikken sprang ud i psykoser (det findes der faktisk mange eksempler på), fik man efterhånden en dulgt fornemmelse af, at noget var galt. Tiderne skiftede og næste slogan blev at vende tilbage til sine egne kulturelle rødder og sanser (de skulle ikke længere være ,røde"), og her fik fagkritikkens egentlige helt: arbejderkulturen en ny renæssance. På forla- 
get ,Tiderne skifter “ kom Hans Jørgen Nielsens „Fodboldenglen" i 1979 - en nøgen skildring af mænd, fodbold, venstrefløjsmiljø og arbejder(krops)kulturen, hvor alle os "fagkritikere" efter at have læst bogen, sad tilbage med en ubehagelig fornemmelse af ramthed. Bogen var et bagholdsangreb på den "røde sanselighed", den forstokkede venstrefløjsakademiker og hykleriet. Den var en varm og kærkommen beskrivelse af et drengemiljø, fodboldmiljø og arbejdermiljø i 50‘ernes Danmark på Amager og en kærkommen og nøgtern beskrivelse af venstrefløjsmiljøet i 60'erne og 70'erne. Den akademiske koldstrøm mod sport blev pludselig trængt tilbage og paradoksalt nok kom opgøret fra en af de mest seje bastioner mod sport nemlig fra det akademiske venstrefløjsmiljø selv 1). Arbejdsfordoblingsperspektivet blev forladt, og vejen for et nyt utopia omkring sporten (fodbolden) var banet.

En af de afgørende banebrydere var Niels Kayser Nielsen med sin artikel „Sport, Kultur og Utopi“ i 1981 2). Et mere realistisk og rummeligt perspektiv på sporten (fodbolden) blev præsenteret $i$ en skarp analyse af sportens dobbelthed: at den er utænkeligt forbundet med industrialisering og kapitalisering. og at den rummer repressive og disciplinerende elementer på den ene side og frigørende, kreative og utopiske kim til fremtiden uden repression og udbytning på den anden. Fodboldspillet blev et såvel teoretisk som historisk eksempel herpå. Vi (os fagkritikere) ku' med god samvittighed begynde at spille fodbold igen, og det væltede ind med indmeldelser i fodboldklubberne, og nye akademiske fodboldklubber dukkede op i Dansk Arbejder-Idræt. Så trillede bolden igen.

Hele denne historie kan vel bedst betegnes som en slags akademisk rodløshed i relation til fodbold - et post-moderne træk som en mere nymoden betegnelse indenfor vores ,"kropsområde“ ville kalde det og måske mere præcist en føljeton i den akademiske verdens identitetskrise, når den skal forholde sig til noget kropsligt/psykologisk. Og her lader den post-moderne diskurs i øvrigt ikke meget tilbage sammenlignet med ideologikritkken, når det gælder defaitisme.
Hvis defaitisme-synet på kroppen og sportens område forlades, og der i stedet fokuseres på teorier, der peger fremad, er der $\mathrm{i}$ realiteten indenfor fodboldspillets historiske udvikling kun produceret to teoritiltag på området: fodboldspillets socialhistorie: dvs. sammenhæng mellem social bevidsthed/erfaring og fodboldspillets udvikling 3) og fodboldspillet forstået som utopisk fænomenologi 4). Disse teorier er så til gengæld blevet brugt (og misbrugt) flittigt i alle akademiske fremstillinger om fodbold, og var egentligt også udgangspunktet, da undertegenede i 1988 på Historisk Institut tog fat på specialeafhandlingen. Teorierne skulle verificeres af ,"historikeren“-hverken mere eller mindre.

Afslutningsvis vil jeg understrege: Når denne "historie" indledes på denne måde, er det for at vise, hvor teoretisk variende og hvor subjektivt udgangspunktet har været indenfor den akademiske verdens forholden sig til fodboldens samtid og historie om FODBOLD. - Men det er jo rart at se, at hjertet banker. Men det gør det også sværere at kritisere hinanden, fordi det et eller andet sted også rammer personlige projektioner.

\section{Myter, teorier, kilder og kildekritik}

Jeg vil i denne artikel koncentrere mig om fodboldspillets tidlige opkomst. De få eksisterende teorier og historiske fremstillinger er stort set blevet udviklet på baggrund af ganske få kilder og historisk benarbejde, hvilket har afstedkommet mange myter, forkerte periodiseringer og heraf også mange forkerte antagelser. Når der tales om fodboldspillets tidlige historie, er der i virkeligheden tale om København. Spillet opstod i København med spæde kim i 1883 og fik først rigtig fodfæste omkring århundredskiftet og fremefter. Fodboldspillet slog ikke igennem i provinsen før efter århundredskiftet og det historiske fortrin, som de københavnske klubber havde, betød en total dominans ikke blot af spillet, men også en total dominans organisatorisk i Dansk Boldspil-Union (DBU) og Københavns BoldspilUnion (KBU) frem til 2. verdenskrig. Spillet og organisationerne fik en kraftig kulturel 
og social slagside med et overklassedomineret hegemoni, hvilket $i$ virkeligheden var et af de helt afgørende forhold, der gjorde dannelsen af DAI mulig i 1929. De små og arbejderdominerede klubber havde på det tidspunkt fået nok af DBU og KBU. Arbejderklassen begyndte imidlertid meget sent at dyrke fodbold, faktisk først omkring år 1900 - og en af de mange myter er, at arbejderklassen spillede fodbold i spillets meget tidlige historie, hvilket jeg efter bedste evne vil forsøge at gendrive $i$ artiklen. En anden myte er, at arbejderklassen introducerede sammenspillet i fodbold med baggrund i en social erfaring og solidaritet i produktionsproces og fagforeninger, mens borgerdyret driblede egoistisk rundt med fodbolden grundet overklassens individualistiske habitus og først begyndte at spille sammen, fordi de var tvunget dertil af arbejderklassens sammenspil. Den historiske virkelighed er omvendt. En sociologisk differentiering og periodisering af fodboldspillets udbredelse, og sociale nedsivning er aldrig tidligere foretaget på baggrund af et historisk materiale (faktisk udelukkende på baggrund af gisninger og spekulationer), hvilket artiklen også vil forsøge at råde en smule bod på.

\section{Boldsportens og fodboldens begyndelse i danmark}

Da sportsbevægelsen slog igennem på kontinentet i slutningen af det 19 årh. og senere den olympiske bevægelse, var den dybest set en borgerlig/aristokratisk avantgardebevægelse indenfor kropskulturens område - det moderne menneske skulle formes og socialiseres ind i de nye tiders udviklingssyn og habitus. De nye industrielle og urbane betingelsers kaos med traditionsopløsning og kulturbrud gav en efterspørsgsel efter nye dannelsesidealer, som sporten som industrikultur var indbegrebet af. Den pædagogiske fortrop med skolelærere, læger, officerer, embedsmænd, industrimagnater, finansfolk, fagforeningsbosser etc. tog opgaven op med seriøs grundighed. De "rene" sportsdiscipliners gennembrud som hestevæddeløb, kapsejllads, kaproning, atletik, kapsvømning etc. smittede efterhånden af på områder som gamle boldlege, der langsomt forsøgtes sportificeret. De første sportificerede boldspil vi kender til i Danmark, var langbold og kricket. Langbold var en del af en selskabelig omgangsform i de "finere" kredse, som Anna Andersen Sellerup beskriver det i sin familiebog om sangforeningen „Danmark", der mødtes og spillede langbold på Østerfælled i København i forbindelse med deres sammenkomster 5).

Den første boldsportsforening vi kender til, er den Kjøbenhavnske Boldspil-klub fra 1866 6). Klubben spillede udelukkende cricket og langbold. Vi kender ikke så meget til dens sociale sammensætning, men underskriverne af indledningen til den vejledning i cricket og langbold, som klubben spillede efter, var udfærdiget af fuldmægtig Schumacher fra Krigsministeriet, kaptajn Hoskjær og grosserer Hansen 7). Kricket og langboldspillet havde ikke tag i den københavnske befolkning (overklasse). Klubben uddøde hurtigt, og i 1876, da andre borgere i København stiftede Københavns Boldklub (KB) som en langboldklub, var denne klub faktisk eneste eksisterende boldsportsklub frem til 1884. Langboldspillet slog aldrig igennem som foreningsspil (men gjorde det dog i folke- og realskolerne). Spillet blev opfattet som for langsomt og stillestående 8). Så forsøgte kvindegymnastikkens fader og krigsassessor Paul Petersen i den nye tids ånd at introducere et nyt langboldspil i midten af $1880^{\prime}$ 'erne, hvor man ikke talte point, men talte kampen i tid. De, der var længst i leg (inde), vandt over det hold, der havde været længst i uleg (marken). Spillet blev talt i 1/4 minutter 9). Men så opstod det groteske forhold, at uleg-holdets opgiver skyndte sig at give bolden op uden, at slåeren var på plads for at undgå tid i uleg. Spillet døde da også hurtigt ud.

KB fra 1876 indførte i 1878 kricket på programmet. $\mathrm{KB}$ havde imidlertid ingen andre modstandere i København, og spillet havde svært ved at slå igennem. Selv staten forsøgte at få spillet introduceret via cirkulærer for samtlige af landets lærde skoler første gang i 1866 og senere i slutningen af 1870 'erne og senere i 1887 , hvor spillet efterhånden begyndte at blive kendt 10). Spillet havde svært ved at bide sig fast og overle- 


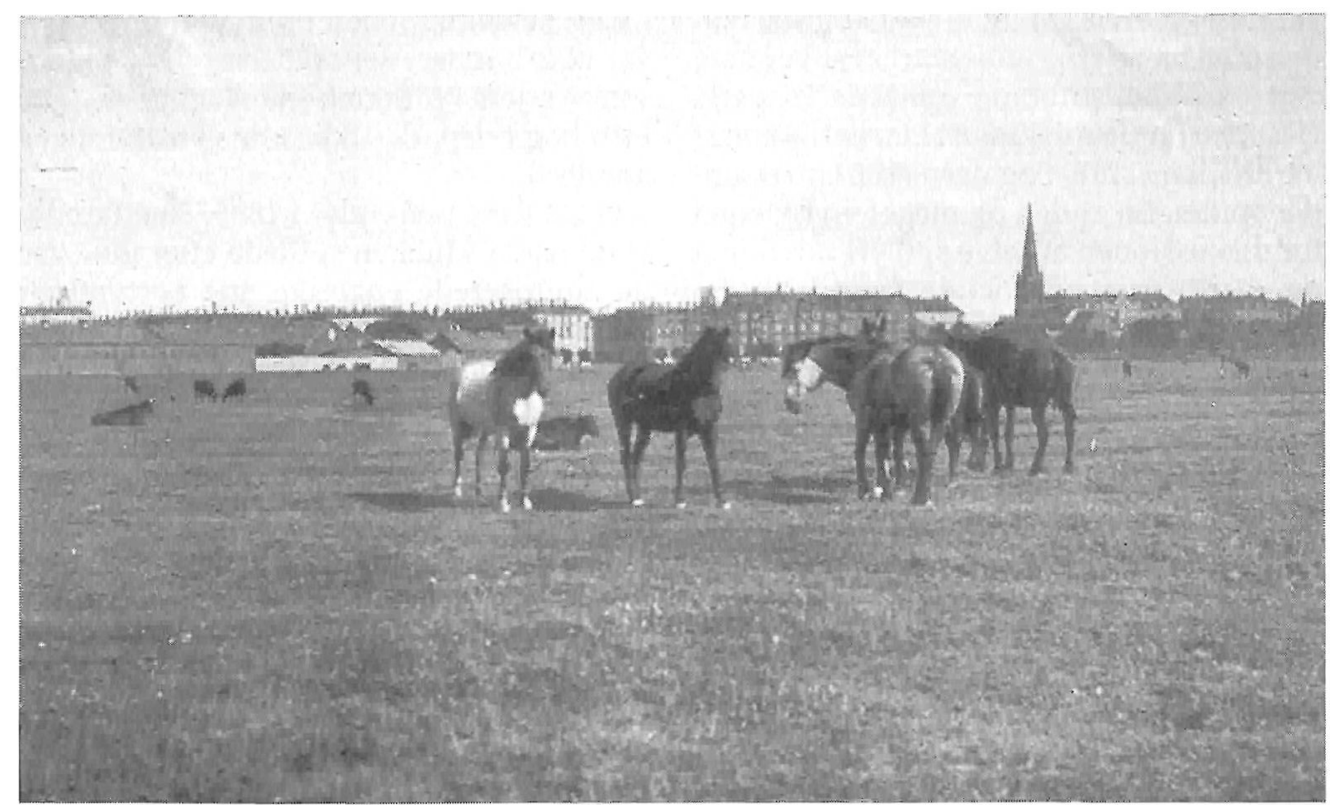

Billed af Københavns Fælled taget omkring århundredeskiftet - endnu inden fælleden blev til Frlledparken. Trianglen ses $i$ baggrunden.

vede på Sjælland kun på de berømte overklassekostskoler Sorø, Birkerød og Herlufsholm 11). Især Sorø Akademi blev storleverandør af kricketspillere til $\mathrm{KB}$ i slutningen af 1870'erne og 1880'erne. KB var eneste kricketspillende klub frem til 1884 i København, og den eneste modstander $\mathrm{KB}$ havde i denne periode var kostskolerne 12).

$\mathrm{KB}$ var en initiativrig og ihærdig klub. På foranledning af KB's egen formand Frederik Markmann - den senere amtmand i Viborg-udsend te klubben i 1881 cirkulærer til de københavnske skoler, hvor klubben tilbød instruktion af spillet på skolerne. Interesserede elever blev inviteret til træning i $\mathrm{KB}$, og ca. 80 elever meldte sig ind i klubben, og herved så Danmarks første ungdomsafdeling i en boldspilklub dagens lys.

\section{Fodboldspillets første år i}

\section{Danmark}

KB besluttede i oktober 1878 at tage fodboldspillet op som aktivitet i klubben som en slags alternativ beskæftigelse til kricket $i$ vintermånederne, hvor det var umuligt at spille kricket 13). Fodboldspillet fik aldrig rigtigt bid bland t klubbens medlemmer, men klubben besluttede imidlertid ved indgangen til næste fodboldsæson at arrangere en opvisningskamp på Dyrehavsbakkens Eremitage-slette i september måned som et propagandafremstød for fodboldspillet. De regler, man spillede efter på dette tidspunkt, var mere rugbylignende end egentlige fodboldregler. Spillet døde fuldstændigt ud i $\mathrm{KB}$ blandt seniorerne - faktisk helt frem til efteråret 1886 14). Den eneste form for fodboldspil, der levede i København frem til 1886 , var KB's forsøg på at introducere spillet i den ovennævnte ungdomsafdeling for kricket. I 1882 fik KB oversat et nyt sæt fodboldregler i kraft af deres personlige kontakt med England. Ungdomsafdelingen spillede efter disse regler i vinteren 1882/83 $\mathrm{og}$ året efter send te $\mathrm{KB}^{\prime}$ s bestyrelse en oversættelse til Birkerød kostskole og fik arrangeret den første fodboldkamp i Danmark i december 1883 mellem KB's ungdomsafdeling og Birkerød kostskole på Rosenborg eksercerplads. Der findes en oversættelse af 1882-reglerne på Rigsarkivet, og af reglerne fremgår det klart, at fodboldspillet stadig havde mange elementer af rugby i sig. Det 
var eksempelvis stadig lovligt at gribe bolden med hænderne ude i marken, hvor man ved en sådan gribning opnåede frispark. Desuden fand tes der ingen klar definition af hårdheden i spillet og dermed frispark under spillet. En anden og meget vigtig regel for diskussionen af selve spillets udvikling og vurdering af sociale bevidsthedsmodaliteter i spillet som fænomenologisk forståelse, således som Hans Jørgen Nielsen har præsenteret teorien om sammenhæng mellem stil og social erfaring, er off-sidereglen. Off-sidereglen fra 1882 foreskriver, at boldholderen ikke må spille bolden længere frem på banen til en medspiller, uden at en modspiller først har berørt bolden. Dette fik den konsekvens, at boldholderpartiet nødvendigvis måtte drible bolden frem eller foretage et spark med bolden op af banen for at komme frem. Hvis bolden blev sparket frem måtte medspilleren ikke røre bolden førend en af modstanderens spillere havde berørt den (dog bortset fra den som havde sparket bolden frem). Denne regel fra 1882-udgaven er selvfølgelig en reminisens fra rugbyspillet. Denne regel faldt først bort med introduktionen af de nye regler, som kom i 1886. Jeg vil senere vende tilbage til denne facet af spillet i diskussionen af appliceringsværdien af den af Hans Jørgen Nielsen introducerede teori på dansk grund i 1978, som faktisk samtlige akademiske fremstillinger om fodboldspillets udvikling har benyttet sig af sidenhen.

\section{De første seniorfodboldkam- pe i 1887 i Kobenhavn}

Fra 1884 begyndte de øvrige kricketklubber ud over KB at dukke op: Fredericia-Studenternes Kricketklub (studenter i København til minde om deres latinskole i Fredericia den senere Akademisk Boldklub AB), Frederiksberg Boldklub (på officerskolens terræn på Frederiksberg slot), Polyteknisk Boldklub (slog sig i 1889 sammen med Fredericia-Studenternes Kricketklub og kaldte sig herefter AB), Melchioraner-Skolens Boldklub (en friskole i København - blev senere til B 93) alle i 1885 og Fremskridts-Klubbens kricketklubi 1886 (stiftet af ledende venstrefolk fra det nye by-borgerskab i København
- blev til Boldklubben Frem året efter. Det var ikke bønder, der spillede i denne klub, som Anders W. Bertelsen fejlagtigt antager i sin bog Frispark - ikke alle venstrefolk er bønder!).

Da KB's bestyrelse i 1885/86 erfarede, at de regler klubben spillede efter ikke var de autoriserede engelske, tog bestyrelsen via en af deres mange kontakter til det engelske samfund initiativ til at få oversat et nyt sæt fodboldregler, nemlig de autoriserede regler fra det engelske fodboldforbund FA. De nye regler blev i efteråret 1886 rundsendt til de sjællandske kostskoler og til underofficerskolen på Orlogsværftet. Den kendte sportspioner og sportsskribent $\mathrm{W}$. Hovgaard var ansat på officerskolen, og KB kontaktede Hovgaard for at få sat den første seniorkamp i Danmark i stand. Kampen blev afholdt på Amager Kasernes grund d. 20. marts 1887. Interessen for kampen var stor. Man ventede spændt på, om de nye regler kunne fungere, og i hvilken grad det havde indflydelse på selve spillet. Hele redaktionen på Tidsskrift for Sport, KB's bestyrelse og interesserede officerer overværede kampen. Underofficerskolen fik lov til at stille op med 15 mand mod KB's 11 - og til trods for dette vandt KB 8-0 15).

Dette blev startskuddet til fodboldspillet i Danmark. De eksisterende kricketklubber, ved årsskiftet i København ca. 5-6 stk. ialt, spillede udelukkende kricket frem til dette tidspunkt, og KB kontaktede 2 af disse Melchioranerne og Fredericia-studenterne med henblik på at spille den første fodboldkamp mellem foreninger. De 2 klubber fik lov at stille fælleshold mod KB, og kampen spilledes i det tidlige forår 1887 på Københavns Fælled. Klubberne gjordeet stort stykke propagandaarbejde for at lokke så mange tilskuere til fælleden, som overhovedet muligt. Der stod imidlertid den pågældende forårsdag en strid vind over fælleden, og kampen blev overværet af ganske få tilskuere. Umiddelbart efter arrangerede $\mathrm{KB}$ en kamp mellem 2 hold fra deres egen klub 2. påskedag. Klubben annoncerede flittigt for kampen, og ikke mindre end ca. 3000 tilskuere troppede op på Københavns Fælled for at overvære kampen - et mægtigt antal også efter datidens forhold 16). 


\section{Boldspil - en modesag i Kobenhavn fra 1887-1889}

Årene fra 1887-1889 kan betragtes som boldspillets take-off-periode. Der blev dog aldrig tale om et egentligt gennembrud for fodboldspillet, idet det faktisk begrænses til ganske få klubber i $1890^{\prime}$ erne. Noget man skal være meget opmærksom på, er, at fodboldspillet var bandlyst om sommeren i de eksisterende kricketklubber. Kricketspillet stod over fodboldspillet, og fodbold blev oprindeligt betragtet som en slags sekundær aktivitet henlagt til vinteren, hvor det alligevel var umuligt at spille kricket. Faktisk blev tennis til at begynde med, da det introduceredes i Danmark og KB i 1882 af oberst Hoskjær, også betragtet som et vinterspil. Jørn Hansen er i et upubliceret materiale inde på samme problemstilling. Kricket var synonym med boldspil i $1880^{\prime}$ erne. Denne sommer/kricket-og vinter/fodboldopfattelse blev overholdt med rigiditet helt ind i begyndelsen af det 20. årh.

\section{Fagforeningernes sportsklubber}

Boldspillet var begyndt at slå igennem i den københavnske middel- og overklasse, men ikke i arbejderklassen. Hermann Trier, Erik Staal (en fremtrædende jurist og politiker i den liberale vælgerforening og medstifter af Boldklubben Frem) og den samlede redaktion på Social-Demokraten tog i fællesskab initiativ til at agitere og holde foredrag blandt arbejdere om sportens og boldspillets velsignelse. Hermann Trier-en utrolig og mangfoldig personlighed - vari det tidlige demokratis historie en pædagogisk, politisk og kulturel begavelse og ildsjæl, og som formand for studentersamfundet fra 1882 til 1907, og som ansvarlig for den gratis undervisning af arbejdere i studentersamfundets regi, tog Trier, den ligeså berømte A.C. Meyer og Erik Staal kontakt til KB's bestyrelse for at formå KB til at stille sig til disposition med henblik på at introducere KRICKET blandt arbejderne. Den mest naturlige måde at få kontakt til arbejderne på var gennem deres fagforeninger 17).
KB stillede sig velvilligt til disposition og drog rundt i de københavsnke fagforeninger for at agitere for sport og kricket sammen med Meyer, Staal, Trier og Julius Heilbuth (medejer af Landmandsbanken, veksellerer, formand og mæcen for Frem). Deres initiativ bevirkede, at der stiftedes 7 arbejdersportsklubber i foråret 1887 18). Der er her tale om Bagernes, Cigararbejdernes, Jernbanearbejdernes, Malernes, Skomagernes, Skræddernes og Typografernes Sportsklub. Samtlige klubber stiftedes som kricketklubber og deres aktiviteter begyndte $i$ april ved kricketsæsonens begyndelse - man spillede som sagt ikke fodbold om sommeren på dette tidspunkt. Det fremgår tydeligt af Typografernes 25 års jubilæumsskrift, at boldspil var ensbetydende med kricket. Først ved sæsonens afslutning diskuterede man blandt typograferne, om man også skulle dyrke anden idræt om vinteren. Der blev stillet 3 forslag: tysk slyngbold, gymnastik og fodbold. Fodbold og gymnastik blev vedtaget. Fodboldspillet havde imidlertid ikke medlemmernes interesse og blev helt taget af programmet i $1892 \mathrm{og}$ blev først taget op igen i 1912 19). Kricketspillet blev det populære blandt typografer og skomagere, især Skomagernes Sportsklub kunne bide skeer med de bedste kricketklubber. Desværre findes der mig bekendt ingen overleverede kilder fra andre end Typografernes Sportsklub. Meget tyder på, at ingen andre end de 2 ovenævnte klubber levede mere end ganske få år (de optræder ikke i nogen kategori af kilder).

Udover dannelsen af sportsklubber i fagforeningernes regi blev der $i$ årene fra 1887-1889 stiftet en lang række af små boldklubber i København. I januar 1888 arrangerede KB Danmarks første større fodbold turnering, som afholdtes på Fælleden. Der tilmeldte sig 15 klubber i alt. Tilmeldingen kostede kr. 3,50 og KB lagde kr. 20,00 i den samlede pulje til præmierne. Ingen af de 7 fagforeningsklubber tilmeldte sig. Cup-turneringen gik over 4 runder og $K B$ vandt med en samlet målscore på 40-0.

En anden begivenhed, der fik indflydelse på rækken af de mange klubber, der skød opi denne periode, må tilskrives Udstillingen i København i 1888. København skulle 
være vært for „Den nordiske Industri-, Landbrugs- og Kunstudstilling" $i$ august og september måned. København var i disse måneder centrum for hele Europas øjne og byen summede af fremskridtets optimisme. Oprindeligt var det ikke meningen, at sport skulle præsenteres som en del af Udstillingens program. Men netop opkomsten af de mangeboldklubber og ikke mindst, at Oberst Hoskjær sad i Udstillingens centrale komité og samtidig var medlem af KB fik betydning. Hoskjær fik sat sport på udstillingens program, og KB formåede at placere sig centralt $\mathrm{i}$ udstillingens sportspræsentation. KB skulle således gå direkte til finaleopvisningskampen i fodbold på udstillingens areal på og ved Tivoli. De øvrige tilmeldte hold måtte spille om den anden plads i finalen, og denne vand $\mathrm{KB}$ som den overlegne klub i disse år.

\section{Friluftslivet i København i 1880'erne}

Egentliger overskriften vildledende-København var på ingen måde nogen venlig friluftslivsby. I realiteten foregik al boldsport i København på militærets velvilje og velsignelse i $1880^{\prime}$ erne og frem til 1893 (i det hele taget synes militærets rolle i den tidlige sports historie meget undervurderet). Den københavnske befolkning led under den katastrofale byplanlægning i slutningen af det 19. årh. (som følge af denne periodes kaos og boligspekulation) og har vel egentlig gjort det siden i store dele af København.

På grund af det københavnske forsvarssystem blev den københavnske befolkning stuvet sammen inde bag enevældens voldsystemer-hvilket stort set vil sige på et areal svarende til det middelalderlige København. I 1860 boede der 155.000 mennesker i boliger med grise, ænder, gæs osv. uden rindende vand, og hvor "natholdet" sørgede for at tømme de åbne „bassiner" med beboernes efterladenskaber, hvilket var en hygiejnisk luksusordning sammenlignet med de boliger, hvor det løb direkte ud i de københavnske rendestene 20). Årsagen til, at folk blev stuvet sammen som sild i tønde, var, at Krigsministeriet med held under stor modstand år efter år ku' fastholde løbende „Be- fæstningsbestemmelser"for Københavns by og befolkning. Bevæggrunden for Krigsministeriet var at fastholde arealerne rund tom København som åbne arealer, således at fjenden ikke kunne nærme sig København ubeset og beskyttet af bygninger og andet på arealet. Disse arealer var i realiteten Københavns fælleder, som lå som en cirkel om København. Glacisystemet var således sidste bastion ud imod fællederne. I 1867 havde alle fået nok und tagen Krigsministeriet, som højlydt beklagede sig over sammenbruddet af militærets overordnededefensionsstrategi af København. De høje hyl og officerstandens centrale magtrolle var en af de væsentligste årsager til Danmarks største byggeskandale gennem tiderne - anlæggelsen af Vestvolden fra 1886 under Estrup, der skulle erstatte det gamle forsvarssystem af København. Frem til 1867 fandtes der faktisk ikke et eneste parkområde indenfor voldsystemet, men kun absolutismens prangende pladser (Kgs. Nytorv, Sct. Annæ Plads, Amalienborg). Ved overdragelsesforretningen mellem stat og Københavns Kommune fik kommunen overdraget Krigsministeriets voldområde, hvilket betød, at de første parker og åndehuller blev planlagt og opført i København med Wien som forbillede (Østre Anlæg,H.C. Orstedsparken, Botanisk Have, store dele af Tivoli og Aborreparken - mellem Vesterport og H.C. Ørstedsparken), idet Wien havde været samme proces igennem 10 år tidligere 21).

Staten og Krigsministeriet fastholdt imidlertid deres rettigheder på et afgørende område, nemlig militærets hævdvundne ret til at eksercere (træne) på de københavnske fælleder. Kongen overgav København samtlige fælleder i 1536, dog med den ene afgørende betingelse, at krigsstyrelsen i København havde ret til at benytte dem til eksercits. Magistraten kæmpede ellers bravt for at få denne restriktion fjernet i 1867, og først i 1893 lå det fast, at militæret og krigsstyrelsen på sigt skulle flytte fra det indre København og ud til den nyanlagte Vestvold. Men først i 1904 havde magistraten og Borgerrepræsentationen frie hænder til at planlægge, hvad fælleden fremover skulle bruges til 22). I kampen mellem stat og kommune blev Københavns fælled et symbol på, hvad kø- 
benhavnerne manglede - et stort og sammenhængende friluftsareal. Læger, skolelærere, socialdemokrater og filantropiske foreninger førte an i kampen. Sports- og friluftsbevægelsen tilsluttede sig denne kamp.

\section{Baggrunden for DBU's stiftelse maj 1889}

Den væsentligste baggrund for stiftelsen af DBU 18. maj 1889 var de manglende muligheder og arealer at dyrke fobold og kricket på. For at få lov til at benytte fælleden måtte klubberne søge Københavns krigsstyrelse ude på citadellet om tilladelse til at spille fodbold. Dette skulle gøres hvert år, og krigsstyrelsen gav klubberne lov til dette mod et symbolsk gebyr på en årlig rente på kr. 1,00. Boldspillene havde dog svære problemer. For det første havde landsbyerne og Københavns borgere stadig ret til at lade heste og køer græsse på fælleden. Dette betød, at klubberne selv måtte stille mål op og tage dem ned efter træning. Og inden dette kunne gøres skulle banen først ryddes for heste, køer og deres efterladenskaber. Militæret gav også KB, i en kort periode i 1880'erne, lov til at benytte eksercerpladsen på Rosenborg slot, som imidlertid var anlagt med sten og grus, hvilket selvsagt gjorde utrolig ondt at falde $i$, og bolden havde desuden uforudsigelige opspring. Desuden opnåede kricketklubben Frederiksberg Boldklub (den har intet med den i dag eksisterende klub at gøre) lov til at spille på Frederiksberg Slots eksercerplads, hvor det samme gjorde sig gældendesom for Rosenborgeksercerplads. Boldspillet udfoldede sig derfor i høj grad på militærets velvilje frem til 1893. Først efter 1893 kunne klubberne benytte fælleden uden problemer og militærets tilladelse.

1. maj 1889 udløb aftalen mellem Krigsministeriet og Københavns magistrat om militærets ret til at anvende fælleden som træningsareal. Under genforhandlingen tabte magistraten atter engang kampen om at få restriktionen fjernet. Umiddelbart før genforhandlingen mellem staten og kommunen om Københavns fælled offentliggjorde $\mathrm{KB}^{\prime}$ s formand Frederik Markmann en artikel i Dansk Sportstidende 23). Markmann gør i artiklen opmærksom på, hvor dårlige betingelser såvel sporten som friluftslivet har i Danmark og især i København. Han stillede derfor krav om, at staten og kommunen skulle afsætte 20-25 tdrl. af fælledens samlede $220 \mathrm{tdrl}$. til rådighed for boldsporten i Købehavn. 4 tdrl. af de 20-25 tdrl. skulle afsættes til „en indhegnet mønsterværdig spilleplads for een eller flere klubber", som skulle afsætte midler ,til dennes realisering" 24). Markmann blev imidlertid skuffet. I slutningen af april stod det klart, at staten ikke ville afgive rettigheder eller arealer til kommunen eller sporten. I al stilhed indkaldte $\mathrm{KB}$ en lille men magtfuld gruppe af klubber til møde om lovudkast til stiftelse af DBU 25). Det er værd at notere sig, at Markmann allerede på dette tidspunkt har en inddeling af boldklubber i forskellige kategorier for øje: nemlig baneejende klubber og falledklubber. Dette blev et centralt tema, $\mathrm{da}$ inddelingen i baneejende og fælledklubber langsom tblev realiseret frem mod århundredskiftet, hvilket gav anledning til heftige politiske slagsmål mellem disse to grupper af boldklubber - mere om det nedenfor.

Den lovforberedende gruppe bestod af 5 klubber: KB, Frem, Melchioranernes Boldklub (det senere B93), AB og Haabet. Haabet uddøde i 1891 og kom aldrig til at spille nogen rolle. Men de resterende 4 klubber blev det senere så berømte "Stævnet" (dvs. de baneejende klubber). Gruppen udsendte invitation til i alt 86 boldklubber fra hele landet heraf 48 fra København, hvilket sandsynligvis var samtlige klubber, som gruppen havde vished om. Der mødte 26 klubber til den stiftende generalforsamling: 20 fra København, 5 fra Jylland og 1 fra Sjælland (Ordrup Kostskole) 26).

\section{DBU - et københavnsk}

\section{magtanliggende}

Den københavnske initiativgruppe stillede forslag om bestyrelsessammensætning, der ville give de københavnske klubber klar overvægt, hvilket især dejyske klubber modsatte sig. Der opstod således allerede fra begyndelsen et modsætningsforhold mel- 
lem København og Jylland. Udgangen på mødet blev et kompromis, der trods alt alligevel gav københavnerne flertal. Det blev besluttet, at der skulle sidde 7 medlemmer i bestyrelsen: 3 fra København, 2, fra Jylland, 1 fraSjælland og 1 fra de øvrige øer (Lolland, Falster og Fyn). Af de 26 fremmødte klubber tilsluttede der sig kun 10 klubber til DBU, 4 klubber fra Jylland (Aalborg, Horsens, Viborg og Kolding), hvor 2 af disse udelukkende spillede kricket, og 6 klubber fra København der alle spillede både kricket og fodbold. De 2 sidste pladser i bestyrelsen fra Sjælland og Øerne blev derfor ikke besat, og blev det aldrig før efter indførelsen af den nye strukturi DBU i 1903. De københavnske klubber fik derfor absolut flertal i bestyrelsen ( 3 ud af 5 pladser) og københavnerklubberne skulle samtidig udgøre det stående forretningsudvalg. Allerede i begyndelsen af $1890^{\prime}$ erne mistede DBU totalt kontakt til de jyske klubber 27). DBU blev derfor udelukkende et lokalt københavnsk anliggende fra 1890-1903. Jyderne tog konsekvensen af forholdeneogstiftede deres egen KRICKETunion - JBU i 1895.

\section{DBU som}

\section{interesseorganisation}

Baggrunden for stiftelsen af DBU var, at boldsporten ikke havde arealer at dyrke sin sport på, og netop dette spørgsmål optog det meste af DBU's arbejde til at begynde med. Boldsporten og sporten i det hele taget havdeikkesamme betydning og anerkendelse som gymnastikken og skytteorganisationerne, som endog havde plads på statens finanslov 28). DBU forsøgte at få politisk anerkendelse ved ansøgning om tilskud på finansloven 1890/91 på et ydmygt beløb på kr. 3-500,00, hvilket blev afslået med begrundelse om, at sport er en privat sag, mens skytte-og gymnastikbevægelsen derimod var en nationalsag 29). Efter stiftelsen $\mathrm{i}$ 1889 indledte DBU et samarbejde med københavnske filantropiske selskaber, der ligeledes arbejdede på at etablere friluftsarealer. Men lige lidt hjalp det - til trods for at presset efterhånden kom fra alle sider i det københavnske kulturliv. Det højredominerede regimente på Københavns rådhus med de københavnske storborgere i spidsen havde ikke til sinds at sælge ud eller give jord væk, som kunne udnyttes til udbygning af boligmassen. Først da Socialdemokratiet og de liberale vælgerlister fik flertal i borgerrepræsentationen i 1898, og den første socialdemokratiske overborgmester i 1903 i magistraten fik idrætten og sporten ørelyd i det politiske system. Sport var og blev en privat sag - jo ny-liberalismen havde godt tag i ideologierne blandt storborgerne.

DBU's historie fra 1889 og frem til 1903 er ikke nogen lykkens historie. Faktisk formåede DBU kun at leve op til én af dens målsætninger - nemlig iværksættelse af en fodbold-og kricketturnering med ensartede regler. DBU's erklærede mål var at organisere boldsporten i hele landet, og DBU bestod jo faktisk udelukkende af københavnske klubber frem til 1903. Fra DBU's første år og frem til 1903 havde DBU kun mellem 5-9 københavnske klubber organiseret. For det andet opnåede DBU ikke offentlige tildelinger som Gymnastik-og Skytteorganisationer gjorde. For det tredie opnåede DBU ikke faste arealer at spille på i København - dette skete først i 1904.

\section{Fodboldspillets udbredelse i København 1887-1911}

Der eksisterer efterhåden en del historiske fremstillinger, der behandler fodboldspillets tidlige historie (Ove Korsgaard, Karl Christensen, Anders W. Bertelsen, Ebbe Hansen, Claus Nørregaard og Hans Bonde). Kendetegnende for disse fremstillinger er, at deres egentlige formål $i k k e$ har været at beskrive og analysere fodboldspillets tidlige historie, men at beskrivelsen af den tidlige fase blot har været brugt til perspektiveringer, der har tjent andre formål i disse omtalte fremstillinger. Det ligger som en urokkelig implikation, at fodboldspillet har gennemgået en jævn fremadskridende udvikling fra KB's første præsentationskamp i 1879 og fremefter. Desuden har det været underforstået, at arbejderklassen fra første færd har været en aktiv del i denne udvikling. Udviklingen har derimod været ganske ujævn og i store perioder frem til århundredskiftet totalt domineret af den københavnske overklasse. 
Ved en nøje gennemgang og analyse af samtlige kildekategorier, som nærværende artikel bygger på, skal det ene øje voves ved at opstille følgende periodisering af fodboldspillets udbredelse i København frem til mellemkrigsperioden 29).

1878-1886: Kostskolefodbold og fodbold i KB's yngre afdeling

1887-1892: Fodbold - en københavnsk modesag

1893-1898: Kriseperiode, som næsten totalt udslettede fodbold i København

1899-1902: Fodboldspillets etableringsperiode, og den er landsdækkende

1903-1939: Fodbold bliver en massebevægelse.

1878-1886: Staten forsøgte ved tidligere omtalte cirkulærer at indføre fodbold og kricket på de lærde skoler i hele Danmark. På Sjælland lykkedes det kun på Sorø Akademi, Herlufsholm- og Birkerødkostskoler. I 1881 dannede $\mathrm{KB}$ en yngre afdeling for kricketspillere, som de rekrutterede i de københavnske skoler. Denne yngre afdeling spillede fodbold om vinteren. Udover fodbold i skoleregi og i KB's yngre afdeling (som også var dannet i skoleregi) fandtes der ikke fodbold i København.1887-1892: Fra at der kun var 4-5 klubber i begyndelsen af 1887 til, at der i midten af 1889 eksisterede ca. 50 boldspilsklubber, vidner om en eksplosionsagtig udvikling, som set i bakspejlet kan være utrolig svær at forklare. Det kan siges med ret stor sikkerhed, at der i København fra 1893-1896 fandtes utrolig få klubber velsagtens mellem 5-8 på samme tid. Hvorfor slog fodboldspillet pludselig igennem fra foråret 1887 og frem til foråret 1889 - efter at boldspilspionerer gennem en lang periode på ingen måde havde fået fodboldspillet til at fænge i den københavnske befolkning? Og hvorfor er fodboldspillet næsten total uddøet i midten af 1890'erne? Der findes en række forhold, der kan have gjort sig gældende.

For det første har en stor del af de ca. 50 klubber, der eksisterede i København været klubber stiftet på folkeskoler, real- og latinskoler, universitet, seminarer, friskoler etc. 30). Hvor mange af disse 50 klubber der er stiftet i denne sammenhæng er umuligt at sige, men jeg har ved registreringen og gennemgangen af samtlige kildekategorier noteret alene 14 klubber, der er stiftet i skoleog uddannelsesammenhæng, og der har ganske givet været mange flere, som jeg blot ikke er støt på.

For det andet har udstillingens fremskridtsånd i København 1888 utvivlsomt smittet af. Især fodboldspillet fik en fremtrædende rolle i udstillingens præsentation af sportsgrene eksempelvis spilledes five-aside-finalen på udstillingens grund $\mathrm{i}$ Tivoli. Fodbold blev en modesag - og som modesager er - de er flygtige.

For det tredie nævnes det i DBU's forhandlingsprotokoller fra 1889, at dobbelt og tredobbelt medlemsskab var et stort problem for unionen, som ikke tolerede medlemsskab af mere end een klub 31). Her skal man huske på, at DBU-klubberne (som var destørste) anså fodbold for at væreet vinterspil og kricket et sommerspil, og det var forbudt medlemmerne at spille fodbold om sommeren i klubregi. Det har således været oplagt, hvis man ville spille fodbold om sommeren selv at stifte eller blot være medlem af en fodboldspillende klub udenfor DBU's regi.

For det fjerde skal man være opmærksom på, at DBU var en union for både kricketog fodboldklubber, og en del af disse må formodes kun at have spillet kricket eksempelvis sportsklubberne stiftet i fagforeningsregi og Melchioranernes Boldklub samt ØB (sammensluttedes i 1893 som kricketklubi B 93).

\section{DBU tæt på udslettelse i midten af 1890'erne}

Fra 1893 og frem til slutningen af 1890'erne kom fodboldspillet ind i en massiv krise og afvandring. KB og Frem er eneste klubber, der har bevaret medlemsprotokoller fra disse år. Af protokollerne kan det ses, at der i denne periode indløbstribevis af udmeldelser. Boldklubben Frem måtte helt indstille deres aktiviteteri 1895/96. Året før tilmeld te der sig kun 3 klubber til DBU's fodboldturnering (Frem, KB og AB), og da Frem meldte fra til næste års turnering var der kun $\mathrm{AB}$ og $\mathrm{KB}$ tilbage. $\mathrm{DBU}$, som således kun bestod af 
to aktive klubber, spurgte B 93, som på daværende tidsspunkt kun spillede kricket, om de ville forsøge sig med fodbold og stille op i turneringen 1895/96, hvilket klubben gjorde 32). I perioden 1893-1897/98 eksisterede der med meget stor sandsynlighed ikke mere end 5-8 boldklubber i København på samme tid 33).

Fodboldens krise var ikke sportsbevægelsens krise. 1890'erne var gennembruddet for mange sportsgrene og -klubber. Der opstod i denne periode kraft-, fod- og især cykelsportsklubber. Især cykelsporten var inde i et kæmpe opsving - måske den nye modegrille i midten af $1890^{\prime}$ erne som afløser for den gamle modegrille fra 1880'erne; nemlig fodbold?.

Spørgsmåleter, om der eksisterede uorganiseret fodbold i denne periode? Ganske givet - men al sandsynlighed taler for i et meget lille omfang. KB's overklassehegemoni havde sat sig igennem i DBU på dette tidspunkt, og det kunne være oplagt, at arbejdere, funktionærer, osv. derfor organiserede eller selv etablerede fodbold. En gennemgang af Socialdemokraten i årene 1895, 1898 og 1900 og Politiken samt Berlingske Tidende i årene 1898 og 1900 giver ingen vidnesbyrd om dette. Konklusionen må være, at fodboldspillet og DBU i denne periode var inde i en dyb krise.

\section{Et forsøg på at bestemme fodboldspillets sociale}

\section{herkomst}

Det er desværre ganske få klubber, der har været opmærksomme på at bevare deres gamle arkiver. Ved en gennemgang af samtlige klubbers arkiver stiftet før 1911 i København findes der i dag kun 3 klubber med medlemslister fra før eller lige omkring århundredskiftet nemlig Frem, B 93 og KB. Som ovenfor antydet udgjorde disse $3 \mathrm{klub}$ ber sammen med $A B$ den faste kerne fra fodboldspillets gennembrud og frem til 1900tallet. Kilderne til de mange små klubber fra årene 1887 til ca. 1891/92 er gået tabt. Meget tyder dog på, at hovedparten af disse udgår fra uddannelsesmiljøet i København. Disse klubber har ganske givet været små, sand- synligvis med 20-30 medlemmer som hovedregel og med medlemmer optrædende i mere end een klub 34). De store klubber var også dengang de 4 ovennævnte klubber. Disse 4 klubber udgjordesenere det såkald te "Stævnet", som stort set leverede samtlige landsholdsspillere frem til efter 2 . verdenskrig, og klubberne havde samtidig en størrelse, der gjorde det muligt at arrangere internationale kampe i København.

Boldklubben FREM er ofte blevet kaldt arbejderklubben, og en enkelt forfatter har endog betegnet klubbens medlemmer som bønder, fordi klubben i 1886 blev stiftet af Venstrefolk i København 35). Klubben blev imidlertid ikke stiftet af 1 . generationsarbejdende bønder i København, men af det nye liberale industriborgerskab.

KØBENHAVNSBOLDKLUBhar-sammen med Frem - bevaret komplette medlemslister i årene 1892/93 med tituleringer ud for medlemmerne. Desværre er medlemslisterne i Boldklubben af 1893 (B93) gået tabt i de første år klubben levede, men klubben har bevaret komplette lister fra 1901 og fremefter. Det er derfor muligt at rekonstruere disse klubbers sociale sammensætning. Der er valgt en inddeling i 3 sociale grupper: en såkaldt overklasse, en middelklasse og en arbejderklasse 36).

Det skal med det samme understreges, at $\mathrm{i}$ tallene for både $\mathrm{KB}$ og $\mathrm{B} 93$ indgår klubbens tennismedlemmer, som ganske givet udgjorde ca $3 / 4$ af det samlede medlemstal. Ligeledes gælder det, at for alle 3 klubbers vedkommende skelnedes der ikke mellem kricket- og fodboldspillere, således at fandtes der spillere som udelukkende dyrkede kricket tæller disse personer også med i tallene. Trods dette faktum var KB fodboldmastodonten, som ingen kom op på siden af med B 93 som den urørlige næststørste.

Akademisk Boldklubs (AB) medlemslister for denne periode er desværre gået tabt. Men AB havde i sine love helt frem til 1964, hvor klubben flyttede fra byen ud til Bagsværd, indføjet et krav om, at de enkelte medlemmer enten skulle være indskrevet på en højere læreanstalt eller have taget afgangseksamen fra en sådan. Ud fra de præmisser, der er opstillet i kriterierne for 


\begin{tabular}{|l|r|r|r|r|r|r|}
\hline & $\mathrm{KB}$ & $\mathrm{KB}$ & $\mathrm{B} \mathrm{93}$ & $\mathrm{B} 93$ & FREM & FREM \\
\hline & antal & $\%$ & antal & $\%$ & antal & $\%$ \\
\hline overklasse & 424 & 82 & 182 & 67 & 13 & 16 \\
\hline middelklasse & 71 & 14 & 75 & 28 & 35 & 42 \\
\hline arbejderklasse & 20 & 4 & 13 & 5 & 53 & 42 \\
\hline I alt & 515 & 100 & 270 & 100 & 83 & 42 \\
\hline
\end{tabular}

skema 1.

den sociale kategorisering i ovenstående inddeling, er $\mathrm{AB}$ at betragte som tilhørende gruppen under overklassen. $A B$ havde $i$ følge DBU's protokoller i 189877 medlemmer. $\mathrm{Da} \mathrm{AB}$ tog tennis på programmet efter århundredskiftet, steg klubbens medlemsantal drastigt 38).

Det kan derfor, med få modifikationer, konkluderes, at størsteparten af de udøvende fodboldspillere i fodboldspillets tidlige historie kom fra overklassen. Modifikationen der står tilbage er, at vi intet ved om ca. 1015 af de i alt 50 klubber i København, der eksisterede i årene fra 1887-1889/90, blot at disse hurtigt uddøde og tilhørte gruppen af småklubber. De resterende klubber, hvilket vil sige størsteparten af aktivt udøvende fodboldspillere, rekrutteredes i uddannelsesmiljøet. Fra 1893 og frem til århundredskiftet eksisterede der kun 3-5 klubber ved siden af de 4 ovennævnte, som kun levede i ganske få år - ØB, der blev stiftet i 1894 (på ruinerne af Frem) er undtagelsen.

Det er derfor en forkert antagelse at betegne småklubberne fra fælleden som arbejderklubber før århundredskiftet 39). Alt peger i modsat retning, og der er under ingen omstændigheder belæg for at betragte fodboldspillet som en arbejderklasseaktivitet før omkring århundredskiftet !!!

\section{Urbanitet, utopi og fodbold}

Ideologikritikken var hård ved fodboldelskerne. Den akademiske åndelige nærhed og kropslige distance gjorde det faktisk umuligt $\mathrm{i}$ universitetsmiljøet at legitimere falsk bevidsthedsadfærd såsom at dyrke sport. Niels Kayser Nielsen introducerede i 1981 på danskgrund Ernst Blochs , positive“ideo- logikritik, som med detektivisk øje fandt kim til frihed, lighed og frigørelse i den kapitalistiske adfærd. Den kapitalaffirmative sport var ikke blot disciplinerende, men bar indogent kreative og frigørende handlemuligheder. Det høje abstraktionsniveau er forsøgt appliceret ind i forhold til en konkret historisk virkelighed, nemlig at sporten opstod i sammenfaldet mellem urbanisering, industrialisering og kapitalisering ,på et tidspunkt hvor vandringen fra land til by var størst for Københavns vedkommende, dvs. i 1880'erne og 1890'erne. Fodboldspillet, fodboldklubben og fodboldkollektivet blev en industriel enkulturalisering for landindvandrerne og 1 . generationsarbejderen, hvor rødderne tilbage til landet, den frie natur og det tabte fællesskab kunne udleves og opleves i fodboldens verden som regressiv længsel i bylivets fornedrelse og undertrykkelse 40).

Den mere humane fortolkning af sport og fodbold gav anledning til en nærmest total ukritisk akademisk brug af teorien, hvor fortolkningernes overdrev er størst $i$ Anders W. Bertelsens best-sællert "Frispark" fra 1983. Teorien har to afgørende forudsætninger, hvis den skal bruges i en konkret historisk situation: for det første at der er tale om fodboldspillende arbejdere, og for det andet at disse kom fra land til by og var 1. generationsarbejdere. Uden at føre nogen form for bevis, postulerer Bertelsen, at boldspillerne i Frem var tidligere landboere. Misforståelsen synes at opstå ved, at Bertelsen antager, at hvis man er tilhænger eller medlem af partiet venstre, må man være en eller anden form for bonde eller have tilknytning til bondelivet, mens virkeligheden er, at stif- 


\begin{tabular}{|l|r|r|}
\hline FØDSELSSTED & ANTAL & $\%$ \\
\hline BYER UDENFOR KØBENHAVN & 12 & 23 \\
\hline KØBENHAVN & 39 & 73 \\
\hline LANDET & 2 & 4 \\
\hline I ALT & 53 & 100 \\
\hline
\end{tabular}

skema 2.

terne og venstrefolkene i Frem tilhørte det nye liberale borgerskab i København (Heilbuth, E. Staal, Østrup etc.) 41). Den anden forudsætning er, at klubbens medlemmer rent faktisk var arbejdere. Som ovenfor vist i skema 1. var Frem den socialt bredest sammensatte klub af de nævnte 4 med $42 \%$ fra arbejderklassen og de øvrige $58 \%$ fra middel- og overklassen. Så at påstå at Frem var en arbejderklub, er en overdrivelse - gruppen udgjorde trods alt mindre end halvdelen af medlemmerne.

Hvis teorien nogen sindeskal verificeres vil det være nødvendigt at undersøge om fodboldklubbernes medlemmer var indvandrere fra landet, som søgte sit kulturopbrud sublimeret eller mindsket i en social og kulturel underskudssituation i København i selve fodboldens verden. Det er sammenfaldet mellem sportens opkomst og de enorme indvandringstal til København i 1880'erne og 1890'erne, der har givet anledning til at forudsætte en sammenhæng mellem disse to forhold. Indvandringen til København var størst i 1890'erne. Her er det værd at notere, at kun ca. 500 spillede fodbold og/ eller kricket i København i midten af 1890'erne (og hvis kricketspillerne kunne fratrækkes, ville tallet blive endnu lavere). Hvis man tager de 5-8 klubber, der eksisterede i midten af 1890'erne og udelukker de ovennævnte overklasseklubber er der kun 2-5 klubber tilbage (Frem, ØB, Efterslægten (uddannelsesinstitution), Dana og Nylon). Af disse eksisterer der i dag kun medlemslister for Boldklubben Frem, og Frem er således enste klub, der reelt kan udsige noget om denne relation. Det har været muligt at undersøge fødselsstedet for
Frems medlemmer, idet medlemslisten for 1892/93 opgav adresse på medlemmerne. Af de 83 medlemmer var det kun muligt at spore 53 .

De 53 personer er ligeligt og relativt fordelt på de sociale kategorier 42). Hvis man med forsigtighed skal udtale sig på baggrund af 53 personer, bekræfter ovennævnte tal i højere grad tesen om den nære relation mellem urbanitet, industrialisering og sportens kropslige legemliggørelse af kapitalismens kumulative bevidsthedsform og ikke agrare bevidstheds-og omgangsformer 43). Dette udelukker jo på ingen måde Kayser Nielsens tese om utopiske kim i sportens grundlag, men udelukker til gengæld brugen af teserne, som Bertelsen har gjort det!!

\section{De baneejende - et magtmo- nopol i dansk fodbold}

Da Københavns Kommune i 1880‘erne og begyndelsen af 1890'erne afviser DBU's krav om tildeling af spillearealer, tog KB sagen $\mathrm{i}$ egen hånd. I løbet af 1892 optog KB forhandlinger med det Højre-dominerede styre på Københavns Rådhus. Kommunen tilbød i slutningen af $1892 \mathrm{~KB}$ et areal på 4 tdrl. på området omkring Julius Thomsens Plads og Sct. Markus allé (der hvor Forum ligger i dag). Dengang hørte dette område under Københavns Kommune (nu Frederiksberg Kommune). Lejen af arealet blev fastsat til kr. 1600,00 om året - et giganstisk beløb for småklubberne med 20-30 medlemmer, hvis kontingent lå på ca. 50 øre om måneden. KB anlagde i løbet af 1894 et eksklusivt tennisanlæg og fodboldstadion. De samlede anlægsudgifter beløb sig til ca. kr. 15.000,00, 
som klubben selv finasierede. Men afdragene kom, alle fodboldklubberne under DBU, inddirekte til at betale.

DBU blev fra stiftelsen og frem til 1903 styret af $A B, K B$ og B 93. I 1894 tvang KB's bestyrelsesmedlemmer i DBU de øvrige klubber til at underskrive en kontrakt, der sikrede KB samtlige kampe i DBU's regi til at blive spillet på KB's nye stadion. Kontrakten sagde, at i kampe, hvor KB deltog, skulle KB have $75 \%$ af indtægten og i kampe, hvor de øvrige klubber skulle benytte KB's stadion, kulle KB have $50 \%$ af ind tægten (selvom klubben ikke spillede), mens de to spillende klubber hver skulle dele $50 \%$ af entreindtægten ligeligt. DBU forpligtede i kontrakten samtlige klubber til, at alle officielle fodboldkampe (internationale kampe, landskampe, turnerings- og pokalkampe) skulle afvikles på KB's stadion. Samtlige klubber modsatte sig forslaget, men blev tvunget af $\mathrm{KB}$ til at bøje nakken 44). Efter denne episode begyndte $A B$ og B 93 selv at søge efter spillearealer, hvor de kunne opnå samme rettigheder og status som KB. Klubberne søgte ligeledes Københavns Kommune og magistrat om spillepladser, hvilket først lykkedes for B 93 i 1901 og AB i 1902. Kommunen afsatte plads til $\mathrm{AB}$ og $\mathrm{B} 93$ på selve fælleden, hvor klubberne fik lov til at indhegne og bygge på arealerne. KB accepterede, at $A B$ og $B 93$ opnåede samme rettigheder til entreindtægter i DBU's regi. Da Frem erfarede, at det kunne lade sig gøre at formå kommunen til at afsætte spillepladser til enkeltklubber, søgte klubben ligeledes om spilleplads. Det Højre-dominerede Rådhus afslog symptomatisk nok den gamle Venstre-klub, som ikke havde samme overklassepræg som KB, AB og B93. Først da de poltiske venner - de liberale og Socialdemokratiet - fik den første Overborgmester post i 1903 kom der gled i sagerne. Kommunen ved overborgmester Jens Jensen anviste Frem et areal på Vesterbro i 1905. Frems ry som arbejderklasseklub stammer i virkeligheden fra denne flytning fra fælleden ud til arbejderkvarteret på Vesterbro. Frems tilhørsforhold til de 3 overklasseklubber, stammer så til gengæld fra, at klubben kom ind i de baneejendes rækker og fik fællesinteresser som baneejende klub med de øvrige baneejende klubber. Disse 4 klubber udgjorde herefter en samlet gruppe i DBU, KBU og Stævnet (1910/11).

\section{Fodboldspillets udvikling til}

\section{massebevægelse}

I årene efter 1900 skød fodboldforeningerne frem som paddehatte. $1890^{\prime}$ ernes krise var ovre. Hvorfor nu det? Et forhold er helt afgørende: Fodbold anbefaledes i 1896 til skoleundervisning i faget gymnastik i Kultusministeriets cirkulære af 31. august 1896 $\mathrm{i}$ „,Cirkulære om indførelse af Lege og Boldspil i Skolerne" 45). I gymnastikkommissionens vejledning fra 1897 anbefalede kommissionen fodbold som særdeles velegnet 46). Jo, gymnastiksagens kamp mod den lystbetonede sport var efterhånden på retræte. Efter cirkulæret af 1896 søgte den københavnske legepladsforening om optagelse på finansloven fra april 1897. Finansministeriet bevilgede et beløb på kr. 5000,00 over en tre-årig periode. Formålet med foreningen var at udbrede kendskabet til ordnedelege og spil, herunder fodbold. Legepladsforeningen antog efter bevillingen et nyt navn „Udvalget for danske Skolebørns Fælleslege", hvor Frederik Knudsen spillede en helt afgørende rolle (se biografi andet steds i denne årbog) 47). Udvalget rejste land og rige rundt og afholdte kurser for skolelærere. I 1899 afholdte skolerne deres første turnering ,Skolernes Pokalturnering“. Et kendtegn for denne periode var, at de mange klubber der stiftedes i denne periode, blev stiftet af meget unge mennesker 48). Et kendetegn der måske kan føres tilbage til, at skoleelever i kraft af skolen fik et kendskab til spillet, der gjorde det muligt selv at organisere fodbold i fritiden. Væksten gjald tikke kun København. Efter århundredskiftet bliver fodboldspillet en landsdækkende massebevægelse. L. Hartoft formand for Sjællands Boldspil-Union (SBU) i 1927 skrev i 25 årsjubilæumsskriftet, at kendskabet til fodbold og dets udbredelse i høj grad skyldtes „Udvalgets" arbejde og kurser for skolelærere 49). Der er ingen tvivl om, at skolerne var fundamentet, som fodboldens udbredelse efter århundredskiftet blev bygget på. 


\section{Fra fælled til Fælledpark}

Efter at ,systemskiftet" på Københavns Rådhus, hvor Socialdemokratiet og de liberale vælgerlister havde fået flertal var den første overborgmesterpost i 1903 ved Jens Jensen en realitet. Et af de forste initiativer Jens Jensen tog var en nedsættelse af et udvalg, der skulle arbejde på at forvandle fælleden til en kæmpe bypark med Hyde Park i London som forbillede. Parken skulle indrettes med idræts- og legepladser for den københavnske befolkning. Det endelige resultat af planlægningen var tilendebragt i 1909, hvor det første parktræ blev plantet af Jens Jensen. En del af projektet var, at der skulle opføres et supermoderne idrætsanlæg kaldet „, Københavns Idrætspark “, som fik overdraget 17 tdrl. for 99 år. De københavnske idrætsorganisationer blev overdraget anlægget som en selvejende institution. K.I. er en af Danmarkshistoriens første pluralistisk sammensatte institution. Det var således KBU, der skulle have fast plads i K.I.'s organer. KBU blev stiftet i 1903, da DBU blev forvandlet til en paraplyorganisation bestående af de lokale unioner fra København, Sjælland og Jylland. Som en del af sportsanlægget var der planlagt dels et Stadion kaldet „Idrætsparken“"og dels et Fælledklubhus til de mange fælledklubber.

På dette tidspunkt havde de baneejende klubber og fælledklubberne indgået et kompromis om, at selvom de baneejende klubber udgjorde et klubmæssigt mindretal og fælledklubberne et flertal, skulle de baneejende fast have 3 pladser i bestyrelsen og falledklubberne 2. Med opførelsen af Idrætsparken var der lagt en bombe under hele magtforholdet i KBU og dermed DBU, der kontrolleredes af KBU. Med opvisningsbanen ville Fælledklubberne pludselig kunneløsrivesig fra de baneejende klubbers kontraktkrav om, at alle officielle fodboldkampe i KBU's regi skulle afvikles på de baneejende klubbers stadions, som gav disse klubber en massiv økonomisk basis. KBU's samlede bestyrelse var indstillet på, at der ville opstå nye tider for hele den københavnske fodboldverden, når Idrætsparken stod færdig. Men en gruppe af folk fra de 4 baneejende klubber begyndte i november

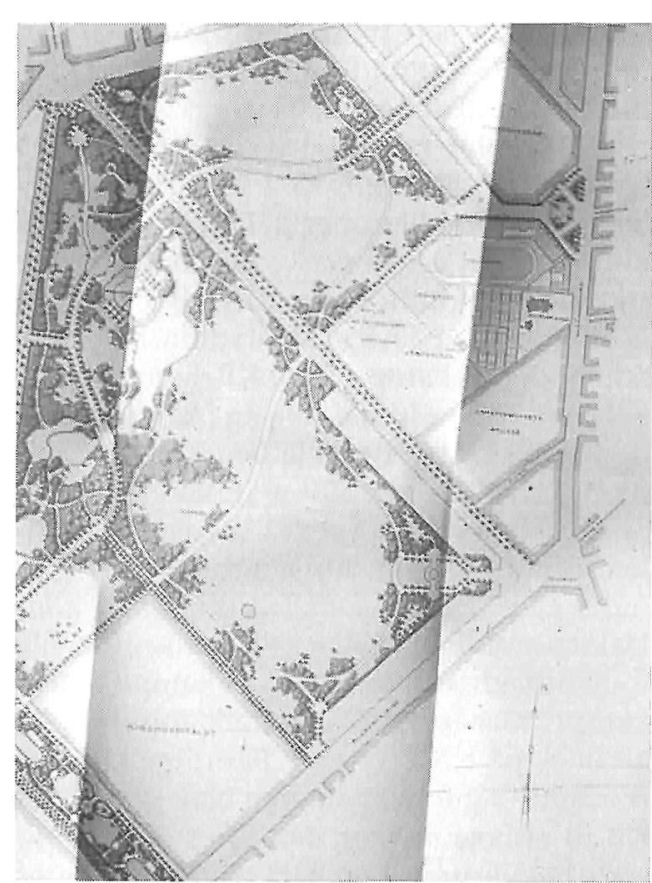

Plan over det vedtagne Fælledparkprojekt fra 1909. Midt på højre side ses "Københavns Idratspark", som det så ud i 1911. Efter datidens forhold - et super moderne stadion

måned i $1910 \mathrm{i}$ al hemmelighed at planlægge et kup mod hele KBU's bestyrelse 50). Alle metoder blev taget $\mathrm{i}$ anvendelse - lige fra manipulationer med forretningsordenen til forsøg på at købe stemmer blandt fælledklubberne. Fælledklubben Dania lod sig lokke og stemte senere sammen med de baneejende. Dette blev klubbens død - den blev frosset ud af de øvrige fælledklubber og uddøde i 1912. Bagholdsangrebet virkede dobbelt-hårdt for debaneejende klubbers egne bestyrelsesmedlemmer i KBU, der stadig i 1928 i KBU's 25 årsjubilæumsskrift gav udtryk for denne skuffelse. Gamle krige plejer ellers aldrig at optræde i jubilæumsskrifter! Problemet var, at kupmagergruppen havdegennemskuet, at fælledklubberne på længere sigt ville få flertal i KBU, og dermed ville overklasseklubberne miste magten, og hvad måske værre var, de ville misteenorme indtægter. Da kupmagergruppen på den ordinære generalforsamling $\mathrm{i}$ 1911 i KBU erfarede, at de ikke havde et 
flertal bag sig udvandrede gruppen. De fik deres klubbers bestyrelse til at bakke dem op og fik senere bestyrelsesmedlemmerne fra de baneejende klubber til at trække sig. Udgangen på det hele blev, at i løbet af 4 ekstraordinære generalforsamlinger i 1911 vand de baneejende klubber slaget om KBU og sammensatte nye regler til valg af bestyrelse i $\mathrm{KBU}$, der umuliggjorde, at de mange fælledklubber kunne overtage magten. Denne magtkonstellation holdt sig helt frem til 1936!!

Da Københavns magistrat i 1910 erfarede, at der var optræk til modsætninger mellem de baneejende og fælledklubberne, og at $\mathrm{KBU}$ ville kunne udelukke fælledklubberne fra Fælledklubhuset, ved tog Borgerrepræsentationen, at det opførte Fælledklubhus, som fælledklubberne kunne benytte som klubhus med omklædningsfaciliteter, ikke skulle høre ind under K.I., men direkte under kommunen, således at såvel fælledklubber under KBU som udenfor kunne benytte anlægget 51).

\section{Københavns fremtidige organisationsudvikling}

Opkomsten af Dansk Arbejder-Idræt (DAI) er altid blevet kædet sammen med en centralistisk beslutning taget i Socialdemokratiet i 1929. Årsagen til at Socialdemokratiet blev opfordret til at organisere arbejderidrætten, var frygten for som i Tyskland, at kommunisterne skulle sætte sig på dette område. Sådan er historien beskrevet i de få fremstillinger om DAI's opkomst i Danmark 52). En kausalitet der går oppefra og ned - men måske er historien en helt anden. I kølvandet på konflikten og udgangen derpå i 1911, blev der i 1912 stiftet fire lokale unioner i København - Nørrebros Boldspil-Union, Valby Boldspil-Union, Nordre-Birk Boldspil-Union og Amager Boldspil Union. Disse unioner slog sig i 1917 sammen under Københavns Forstadsklubbers BoldspilUnion. Unionen havde tilsammen ca. 1500 medlemmer 53). Samme år havde KBU ialt ca. 4300 aktive 54). De baneejende udgjorde ca. 3100 og i hvert fald 3/4 var tennismedlemmer i disse klubber. Tennis hørte under DBU frem til 1920 og talte med i unionens medlemstal. Der var således ca. 1900-2000, der spillede fodbold og kricket i KBU i 1917. Tallet er maximalt, og der har sansynligvis været færre antal dels pga. at kricket har talt med, og dels kan det aflæsses af, hvor mange fodboldhold klubberne havde på dette tidspunkt. De to konkurrende unioner har således været næsten lige store, og til trods for dette har forstadsklubberne levet en upåagtet tilværelse. Forstadsklubberne søgte om optagelse i KBU i 1918 og blev optaget som en underafdeling uden indflydelse i KBU!!! De dårlige erfaringer med $\mathrm{KBU}$ betød, at fodboldklubberne udenfor KBU samledes sig i en ny organisation i 1926 ved navn „Småklubbernes Sammenslutning". Denne sammenslutning voksede hurtigt og havde i 192933 medlemsklubber 55). Stifteren af DAI Aage Hermann tog i 1929 kontakt til sammenslutningen og opfordrede denne til at skifte navn til Arbejdernes Boldspil-Union, hvilket sammenslutningen tilsluttede sig. Aage Hermann overtalte 2 måneder senere ABU til at træde ind i et endnu ikke stiftet forbund ved navn DAI 56). ABU indvilgede og udgjorde byggestenen og kernen i DAI i DAI's første periode. Stiftelsen af DAI ville aldrig have været så smertefri og medlemstallet så stort, som tilfældet var uden KBU's klassepolitik. DAI var ikke kun et centralistisk påfund, men havde også en materialiseret utilfredshed at bygge på.

\section{Afslutning og perspektiveringer}

Da jeg i sin tid engang i løbet af 1988 begyndte at arbejde med fodboldspillets historie, havde jeg den intention, at NU skulle teorierne verificeres af "historikerens" arbejde. Men som artiklen viser, bygger de fleste teoritiltag og abstraktioner på myter og påstande på "den blinde side" af kildernes kedelige "sandhed". Et andet eksempel på, hvor svært det er at bevæge sig på en høj abstraktion til en konkret historisk virkelighed, er teorien om forholdet mellem social bevidsthed som erfarings- og adfærdsgrundlag for sammenspillets opkomst i fodboldspillet. Hans Jørgen Nielsen introducerede i 1978 i en artikel i dagbladet ,Information", som senere tryktes i bogform, i 1980 


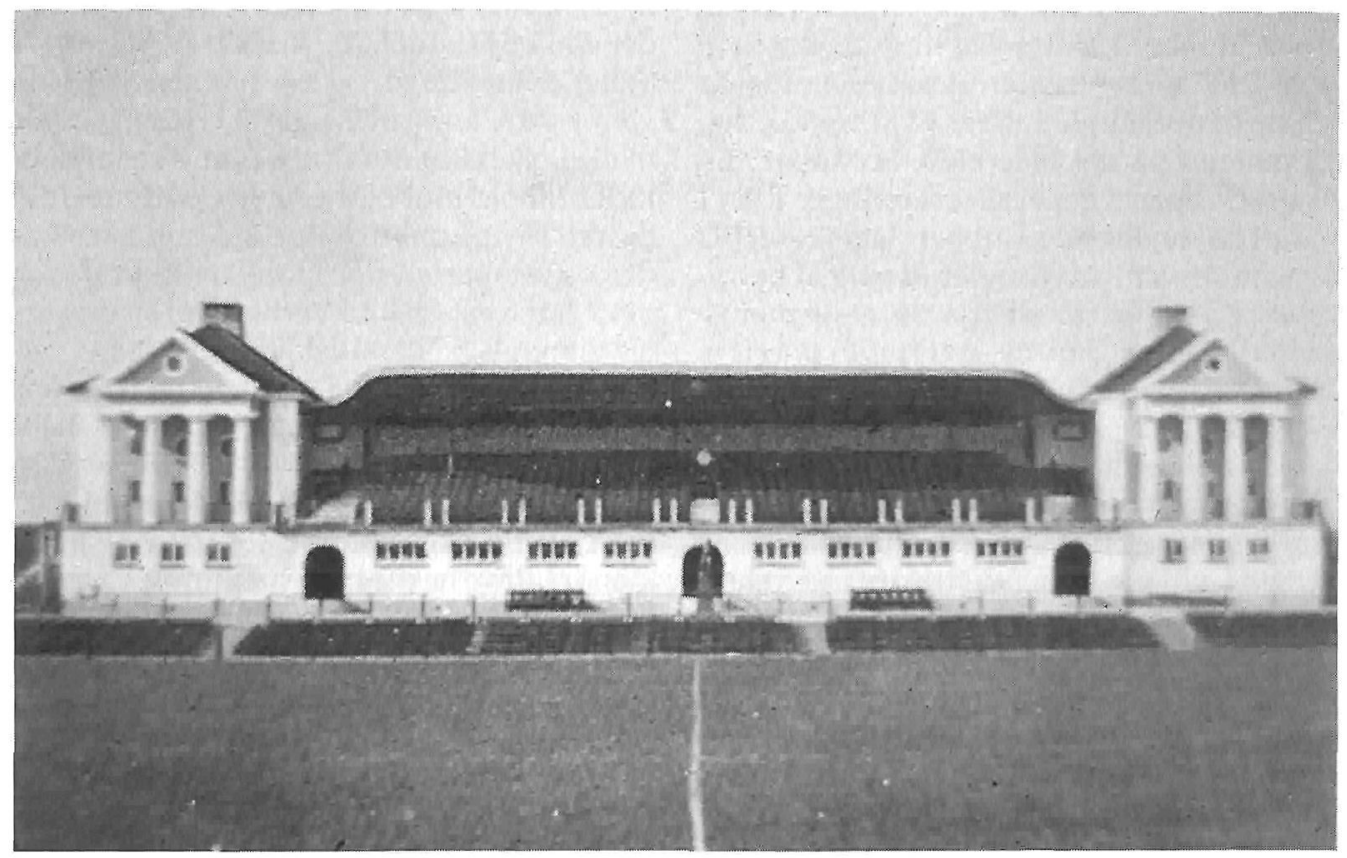

Fælledklubhuset set fra bagsiden, der vender ind mod Idrætsparkens opvisningsbane.

Fælledklubhuset blev hjemsted for de mange falledklubber $i$ København. Fælledklubberne havde omkladnings- og banefaciliteter, kantine og klubhuslokaler. I dag er falledklubberne henvist til kælderen under cementtribunen.

teorien om, at arbejderklubberne gennemførte sammenspillets kunst i fodbold. To spilsystemmer stod overfor hinanden. Overklassens eller borgerens driblefodbold og arbejderklassens kollektive og solidariske sammenspil. I arbejderklassen løfter man i flok, mensindividualiteten og egoismen gror blandt borgere. Dette har faktisk været en ugendrivelig "sandhed" i mange år.

Men den "rigtige" historie er, at overklasseklubberne i DBU i 1898 inviterede det skotske hold "Queens Park" til Danmark. Her mødte et udvalgt DBU-hold skotterne. Herom skriver Nils Middelboe:

Omtrent på dette tidspunkt skete der noget epokegørende i dansk Fodbold. Det var den skotske Amatørklub, Queens Park's Besøg i Maj-Juni Maaned 1898. Ved et enestaaende Tilfalde saa jeg, sammen med min Bro'r Einar, rigtigt Fodboldspil for forste Gang, det blev spillet herhjemme. 57)

Fra denne dag opstod der en "skotsk fodboldfeber" i de københavnske DBU-klub- ber. Sammenspillets kunst skulle læres, som skotterne mestrededet. Debaneejende klubberindførte detskotskesammenspilssystem, og de fremtidige DBU-instruktører, som tog rundt $\mathrm{i}$ landets klubber kom fra de baneejende klubber. De baneejende klubber mestrede efterhånden spilsystemer, og i 1910 bestod landsholdet, der mødte England på KB's bane, udelukkende af baneejende klubbers spillere. Vi bankede, som det første land nogensinde, England med 2-1. Uden at gå i dybden skal det blot nævnes, at KB allerede i 1890 forsøgte at fastholde sammenspilssystemer 58). Sammenspillets indførelse i Danmark må tilskrives overklasseklubberne i Danmark 59). Et andet forhold, som ingen har været opmærksom på, var de eksisterende off-side-regler, der nødvendigvis medførte, at boldholderen måtte driblesig frem på banen, idet off-sidereglen forbød at spille en medspiller længere fremme på banen (denne regel eksisterer stadig i den engelske udgave af rugby) 
(se iøvrigt afsnittet ovenfor: Fodboldspillets første år i Danmark).

Generelt kan man sige om de hidtidige fremstillinger: Arbejderklassen har fået en for stor og alt for tidlig rolle. Fodbold blev først arbejderklassens spil efter år 1900. Overklassen dominerede såvel organisatorisk som i antal af udøvende fodboldspillere som i spilsystemers indførelse. Ligeledes er fodboldspillets udbredelse og gennembrud blevet tillagt et for tidligt tidspunkt.

Mentalitetshistorisk betragtet er det måske heller ikke så underligt endda: nemlig at industrialiseringens og kapitaliseringens logik og habitus i højere grad må forventes at være synlig i den nye magtrelation omkring kapitalismens gennembrud, som borgerskabet var bærere af. Måske kan der argumenteres for, at fodbold i stor udstrækning i sportens tidlige fase fortrinsvis blev udøvet af mænd under uddannelse i $K ø$ benhavn - den kommende magt og bærere af tidens nye trends.

\section{Noter:}

1) Kayser Nielsen: De (h)vide mål og det grønne græs. Den jyske Historiker 19/201981 A.

2) Kayser Nielsen: Sport, kultur og utopi. Bidrag nr 13/14 1981 B.

3) Hans Jørgen Nielsen: Billeder i en verden i bevægelse. !1980. Trykt første gang i Information 1978.

4) Kayser Nielsen 1981 B.

5) Hans Helge Madsen: Østerbros herligheder. København 1986. s. 41.

6) Haandbog $i$ Cricket og Håndbold. København 1866. Rigsarkivet under DBU.

7) s. sted.

8) KB 1901 s. 17.

9) Frederik Knudsen: Lege og Boldspil. København 1931. Langboldspillet.

10) Cirkulære om optagelse af cricket på de lærde skole i Danmark. Tidsskrift for sport 1885 s. 269-274 og William Hovgaard: Sport Kjøbenhavn 1888 s. 39.

11) Tidsskrift for sport s. sted.

12) Der fandtes dog to andre kricketklubber ved navn Dæk og Københavns Kricketklub, som fusionerede med KB i 1880 umiddelbart efter deres stiftelser. Toft s.13-14.

13) KB's forhandlingsprotokol oktober 1878.
14) Tidsskrift for sport 1884 s. 540 og 1886 (samtlige fodboldreferater) og gengivelse af $\mathrm{KB}^{\prime} \mathrm{s}$ generalforsamlingsreferat for $1885 \mathrm{i}$ Tidsskrift for sport 1885 s. 516.

15) Tidsskrift for sport 1887 s. 114-120 og J. Gandil: Dansk Fodbold. s. 26-30. Kobenhavn 1939.

16) Gandil 1939 s. 30 og Tidsskrift for Sport 1887 s. 267-69.

17) Ebbe Hansen 1981 har i sin fremstilling af DAI og arbejdernes tidligesports-og idrætsudvikling indplaceret disse sportsklubber i en produktionsmådediskussion, hvor arbejderbevidstheden endnu var "umoden" grundet Danmarks manglende industriudvikling, og at disse klubber derfor repræsenterede en lavsbestemt bevidsthedsform (s. 146). Hansen er ikke opmærksom på, at disse sportsklubber netop stiftedes i fagforeningregi.

18) Tidsskriftet Idræt 1895 30.5., Typografernes Sportsklub 1912s.5-11., Social-demokraten 1887 15-3. og 20-4., og Tidsskrift for Sport 1887 s. 478 og Dansk Sportstidende 1888-95.

19) Typografernes sportsklub 1912 s. 5-11 og s. 126.

20) Axel Holmog Kjeld Johansen: København 18401940. København 1941. s. 39ff.

21) Samling af bestemmelser vedrørende Københavns Kommune 1864-1874 6/6 1867. København 1878.

22) Borgerrepræsentationens Forhandlinger (BRF) 65.årg. 3.okt.1904.

23) Dansk Sportstidende 1888 s. 384-85.

24) Som note 23.

25) Boldklubben Frems forhandlingsprotokoller april 1889.

26) Dansk Sportstidende 1889 s. 183 og DBU's forhandlingsprotokol 1889.

27) DBU's forhandlingsprotokoller 1889-1895.

28) Niels Kayser Nielsen: Et overset kapitel om sporten og gårdmandslinjen $i$ dansk idrætshistorie. s. 188ff. I: Den engelske sports gennembrud i Norden DHL 1989.

29) Denne vurdering er foretaget på baggrund af følgende kildekategorier:

1. Indsamling af alt eksisterende kildemateriale fra før år 1900 i de københavnske klubber. Desværre er der gået utrolig meget tabt, men KB, Frem, AB, ØB og B 93 har bevaret store dele af deres arkiver (ofte fundet mellem pølsepapir og hjørneflag).

2. Gennemlæsning af samtlige sports-og idrætstidsskrifter for hele perioden.

3. DBU's arkiv og Rigsarkivets DBU-materiale.

4. Aviser: Social-Demokraten 1887, 1895, 1898 og 1900, Politiken 1898 og 1900 og Berlingske Tidende 1898 og 1900.

5.J.Gandil: Dansk Fodbold.50årsjubilæumsskrift for DBU i 1939 (en hovedkilde til fodboldspillets tidlige historie). 
30) Eksempler: Metropolitanskolen, Hauchs skole, Nørrebro latin-og realskole, Hygeia (studenterklub), Jonstrup Semininarium, Slomanns skole, Orlovsværftetselevskole, Officerskolen på Frederiksberg (FB), Efterslægten, Velgjørenhedsselskabets skole, Westendske institut, Polyteknisk, Melchioranernes B.og Fredereciastud. Disse 14 klubber stiftedes i skole- og uddannclsessammenhæng. De 14 klubber, der her er registreret som stiftet frem til maj 1889, er alle klubber, som jeg ved gennemgangen af samtlige kilder er støt på. Udover disse fandtes der jo ganske givet endnu flere, som jeg bare aldrig er støt på!!!

31) DBU's forhandlingsprotokol 1889.

32) Gandil 1939 s. 48ff.

33) Se note 29.

34) Gandil 1939 s. $27 \mathrm{f}$

35) Anders W. Bertelsen: Frispark. København 1983 s. $39 f$.

36) Overklassegruppen består af folk med universitetsgrad, selvstændige erhvervsfolk og direktører herunder veksellerere og grosserere, folk med adelstitlerne greve og baron og officerer fra lieutenant og opefter. Desuden er studerende fra højere læreranstalter med titlet som stud. med. polyt. theol, jur.og mag. Dette valg begrundes med, at folk med universitetsstudier bag sig enten allerede tilhører overklassen eller kommer til det. I middelklassen er folkeskolelærere, kontorister og assistenter placeret sammen med selvstændige håndværksmestre. I gruppen med arbejderklassefolk er såvel faglærte som ufaglærte placeret.

Udfærdiigelsen af optællingen er foretaget på følgende præmisser: Alle kvinder er taget ud, for det første fordi gruppen ikke talte med i DBU's officielle tal, og for det andet fordi kvinderne blot var tituleret med "Frøken" og „Frue". Der var kvindelige medlemmer i B93 og $\mathrm{KB}$ og ikke i Frem. Alle passive medlemmer er trukket ud, idet disse heller ikke talte med i DBU's officielle tal, og fordi interessen her fokuserer på den fodboldudøvende. Alle medlemmer, hvis titel ikke var nævnt er ikke talt med, således at det aktive medlemstal er tendentielt højere.

37) Bertelsen 1983, Ebbe Hansen 1981, Bonde 1986 og Karl Christensen 1983.

38) Jeg er her citeret i Hans Bondes bog s. 154 note 65 med henvisning til mit speciale fra 1990 for, at overklassen lod fodboldspillet ligge til fordel for tennis, hvilket jeg ikke kan forstå. Dette nævner jeg intet steds. Tværtimod er fordommene $\mathrm{i}$ overklassen mod fodbold efterhånden forsvundet, og overklasseklubbernes fodboldspillere steg kraftigt i antal ovenpå 1890'crnes krise!!!!

39) Bonde 1986 157ff, Bertelsen 1983 s. 19ff, Christensen 1986 s. $25 \mathrm{f}$ og s.28f.
40) Kayser Nielsen 1981B.

41) Bertelsen 1983 s.16-42.

42) Toft 1990 s. 78f. Kun større købstæder er medregnet som byer udenfor København.

43) Hans Bonde har ligeledes med inspiration fra Kayser Nielsens Utopi-artikel fra 1981 taget dette emne op i artiklen Frem med bolden fra 1986. Bonde konkluderer på baggrund af Niels Ole Finnemanns bog i Broderskabets ånd, at sporten på linie med socialdemokratismen, grundtviganismen og det moderne gennembrud kan opfattes som et 4 . hjul til disse kumulative bevægelser. Der er dog her tale om paradigmesammenblanding, idet Finnemann udelukkende taler om frigorelsesbevægelser, der indeholder kumulative træk.

44) DBU's forhandlingsprotokoller 1894/95.

45) Idræt 1899 s. 663.

46) Gymnastikkommissionens vejledning af $1897 \mathrm{~s}$. 66.

47) Idræet 1899 s. 663.

48) Toft 1990 s. 108

49) SBU 25 år 1902-1927 indledningen.

50) Protokol med disse møder er fundet i $A^{\prime}$ 's arkiv. Protokollen er ført fra november 1910 til juli 1911.

51) Borgerrepræsentationens forhandlinger 71.årg. bind $1 \mathrm{u}$. Fælledparken og 72 . årg. bind 1 under Fælledparken og K.I.

52) Hansen 1981 s. $152 \mathrm{ff}$.

53) Fodboldbladet $1917 \mathrm{nr}$. 27. Organ for disse unioner.

54) KBU's protokoller 1917.

55) Dansk idræts bog s.1093 og Dansk Sportsleksikon b.2 s.482 og DAI gennem 10 år s. 7 .

56) Som note 55.

57) Middelboe 1944 s. 9.

58) Markmann 1890 s. 516.

59) Se endvidere Toft 1990 s. $81 \mathrm{ff}$.

\section{Litteratur:}

Alstrup, Aksel: Jysk fodbold i fortid og nutid. Odense 1950 og 1953.

Andersen, Evald: Dansk Boldspil-Union 1889-1964. København 1964.

Bertelsen, Anders W.: Frispark. København 1983.

Bonde, Hans: Frem med bolden! Utopi og fremskridtsideologi i den tidlige danske arbejdersport (1880-1920). SFAH København 1986.

Bonde, Hans: Mandighed og sport. OU 1991.

Christensen, Karl: Fodboldspillet-teori, historieog fascination. Speciale Aarhus Universitet 1983.

Christsen, Karl: Hvorfor fodbold blev massespil i Danmark. I: Idrætshistorisk årbog 1986.

Dansk Sportsleksikon. Kebenhavn 1944. 
Finnemann, Niels Ole: I broderskabets ånd. Kobenhavn 1985.

Gandil, Johannes: Dansk fodbold. København 1939.

Haandbog i Cricket og langbold. København 1866.

Gyldendals Danmarks Historie. bind 6.

Hansen, Ebbe: Arbejderidrætten i Danmark med sxrlig henblik på DAI i perio den 1929-1943. Den jyske historiker 19/20.1981.

Hansen, Victor: Illustreret Idrætsbog. København $1890 / 1893$.

Hermann, Aage: Dansk Idræts Bog. København 1934

Holm, Axel og Kjeld Johansen: København 1840-1940. København 1941.

Hovgaard, W.: Sport. Kobenhavn 1988

KB 25 år. København 1901.

KBU 25 år. 1928.

Knudsen, Frederik: Legeog boldspil. København 1931.

Korsgaard, Ove: Kampen om kroppen. København 1982.

Madsen, Hans Helge: Østerbros herligheder. København 1986.

Middelboe, Nils: KB-Chelsea og hjemigen. København 1944.

Nielsen, Hans Jørgen: Billeder $i$ en verden i bevægelse. 1980.

Nielsen, Niels Kayser: De (h)vide mål og det gronne græs. Den jyske historiker 19/20.1981 A.

Nielsen, Niels Kayser: Sport, kultur og utopi. Bidrag 13/14 1981B.

Nielsen, Niels Kayser: Et overset kapitel -om sporten og gårdmandslinjen $i$ dansk idrætshistorie. I: Den engelske sports gennembrud i Norden DHL 1989

Nørregård, Helge: Fodbold og samfund - udvikling, proffessionalisering. Speciale Aarhus Universitet 1980.

SBU 25 år. København 1928.

Politikens Danmarks Historie. bind 11 og 12.

Toft, Jim: Fodboldbanen kridtes op. Speciale Københavns Universitet. 1990.

Typografernes sportsklub 1887-1912. København 1912.

\section{Arkiver:}

AB: Forhandlingsprotokol 1910-1911.

B 93: Medlemsprotokoller 1901-1902.

DBU: Forhandlingsprotokoller 1889-1899 og 1903-1914.

Frem: Forhandlingsprotokoller 1886-1890 og 1895-1910. Medlemslister 1892/3.

KB: Medlemslister 1885-1894. Forhandlingsprotokoller 1887-1892 og 1901-1909.

KBU: Medlemsoptegnelser 1903-1911.

Rigsarkivet: arkivnr. 10.519 DBU pakke 1-3.

Borgerrepræsentationens forhandlinger 1888-1911.

Samling af bestemmelser vedrørende Københavns Kommune 1864-1896 (3bind).

\section{Medlemsblade:}

Fodboldbladet 1916-1920: Officielt organ for Amager-BU, NordreBirk-BU, Valby-BU og Nørrebro-BU. Unionsbladet 1916: Officilet organ for Amager Boldspils-Union.

\section{Aviser:}

Berlingske Tidende 1898 og 1900.

Politiken 1898 og 1900

Social-Demokraten 1887, 1895, 1898 og 1900.

\section{Tidskrifter:}

Tidsskrift for sport 1884-1887.

Dansk Sportstidende 1888-1894.

Idrætstidende 1896.

Dansk Idrætsblad 1898-1908.

Idræt 1895-1901.

Boldbladet 1902.

Idrætten 1905-1912. 
